\title{
Recent glacial recession in the Rwenzori Mountains of East Africa due to rising air temperature
}

\author{
Richard G. Taylor, ${ }^{1}$ Lucinda Mileham, ${ }_{5}^{1}$ Callist Tindimugaya, ${ }^{2}$ Abushen Majugu, ${ }^{3}$ \\ Andrew Muwanga, ${ }^{4}$ and Bob Nakileza ${ }^{5}$ \\ Received 15 February 2006; revised 10 April 2006; accepted 12 April 2006; published 17 May 2006.
}

[1] Based on field surveys and analyses of optical spaceborne images (LandSat5, LandSat7), we report recent decline in the areal extent of glaciers in the Rwenzori Mountains of East Africa from $2.01 \pm 0.56 \mathrm{~km}^{2}$ in 1987 to $0.96 \pm 0.34 \mathrm{~km}^{2}$ in 2003 . The spatially uniform loss of glacial cover at lower elevations together with meteorological trends derived from both station and reanalysis data, indicate that increased air temperature is the main driver. Clear trends toward increased air temperatures over the last four decades of $\sim 0.5^{\circ} \mathrm{C}$ per decade exist without significant changes in annual precipitation. Extrapolation of trends in glacial recession since 1906 suggests that glaciers in the Rwenzori Mountains will disappear within the next two decades. Citation: Taylor, R. G., L. Mileham, C. Tindimugaya, A. Majugu, A. Muwanga, and B. Nakileza (2006), Recent glacial recession in the Rwenzori Mountains of East Africa due to rising air temperature, Geophys. Res. Lett., 33, L10402, doi:10.1029/2006GL025962.

\section{Introduction}

[2] Tropical alpine glaciers serve as highly sensitive indicators of tropical climate [Wagnon et al., 1999; Francou et al., 2003] that are particularly valuable in areas where meteorological records are scarce. In the East African Highlands, glaciers have been shrinking over much of the 20th century [Hastenrath and Kruss, 1992; Kaser and Noggler, 1996; Kaser and Osmaston, 2002; Thompson et al., 2002]. Mapping of glacial extent in the Rwenzori Mountains that straddle the border between the Democratic Republic of Congo and the Republic of Uganda $\left(0^{\circ} 10^{\prime}\right.$ to $0^{\circ} 30^{\prime} \mathrm{N}, 29^{\circ} 50^{\prime}$ to $30^{\circ} 00^{\prime} \mathrm{E}$ ) (Figure 1), was, however, last conducted more than a decade ago [Kaser and Noggler, 1991; Talks, 1993] and debate persists regarding the nature of climate change in these highlands [Hay et al., 2002; Patz et al., 2002; Kaser et al., 2004].

[3] The first survey of glaciers in the Rwenzori Mountains was conducted in 1906 by the Duke of the Abruzzi [1907] when the glacial cover over the entire range was estimated to be $6.5 \mathrm{~km}^{2}$ [Kaser and Noggler, 1996] and the lowest altitude of glaciation is thought to have reached 4400 metres above mean sea level (mamsl) [Osmaston,

\footnotetext{
${ }^{1}$ Department of Geography, University College London, London, UK.

${ }^{2}$ Water Resources Management Department, Directorate of Water Development, Entebbe, Uganda.

${ }^{3}$ Meteorology Department, Kampala, Uganda.

${ }^{4}$ Department of Geology, Makerere University, Kampala, Uganda.

${ }^{5}$ Department of Geography, Makerere University, Kampala, Uganda.
}

Copyright 2006 by the American Geophysical Union. 0094-8276/06/2006GL025962
1989]. Scientific surveys carried out in the 1950s [Bergstrøm, 1955; Whittow et al., 1963] and early 1990s [Kaser and Noggler, 1991, 1996; Talks, 1993] indicate a continuing trend of glacial recession though a brief episode of terminal advance was observed in the early 1960s [Whittow et al., 1963; Temple, 1967]. This coincides with a period of anomalously high precipitation when the levels of Lake Victoria rose by $2.5 \mathrm{~m}$ [Kite, 1981].

\section{Methodology}

[4] Recent glacial recession was assessed by field mapping of the terminal positions of previously monitored 'indicator' glaciers, Elena and Speke (Figure 1b), and quantitative interpretations of snow and ice cover using optical spaceborne imagery (LandSat5, LandSat7). Field surveys of glacial termini on Mounts Speke and Stanley using a handheld global positioning system (GPS) were conducted in June 2003 and January 2005. These included an assessment of the distance between observed termini and the positions of terminus markers set in 1958 [Whittow et al., 1963] and 1993 [Talks, 1993].

[5] Changes in the areal extent of glaciers were assessed using two geometrically corrected LandSat5 (TM) and one systematically corrected LandSat7 (ETM+) optical satellite image accessed from the United States Geological Survey (http://edcdaac.usgs.gov and http://glovis.usgs.gov). Three LandSat images with views of the still glacierised summits unobstructed by clouds were identified in 1987 (7th August), 1995 (17th January) and 2003 (31st January). In the inner tropics where diurnal variations in mean air temperature $\left(\sim 8^{\circ} \mathrm{C}\right)$ significantly exceed seasonal variations $\left(\sim 2^{\circ} \mathrm{C}\right)$ [Kaser and Osmaston, 2002 and references therein], ablation on glacial tongues occurs throughout the year. Snow falling below glacial termini in the Rwenzori Mountains is subject to rapid melting through daily ablation during daylight hours and accumulation is confined to high glacial areas during periods of heavy precipitation (rainy seasons). The areal extent of snow and ice inferred from satellite imagery was, therefore, considered to represent glacial cover.

[6] LandSat images were subsampled to create specific images of each mountain in the Central Rwenzori Massif (Figure 1b). Areal extent of snow and ice was determined using supervised classification (SC) on a false-color composite of bands 2 (visible (green), 0.52-0.60 $\mu \mathrm{m}), 4$ (near infrared, $0.75-0.90 \mu \mathrm{m}$ ) and 5 (mid-infrared, 1.55-1.75 $\mu \mathrm{m}$ ) as this best represents snow [Vogel, 2002]. To test the accuracy of estimates derived from SC, the deduced areal extent of glaciers was also calculated using the Normalised Difference Snow Index (NDSI) (equation 1). The NDSI 


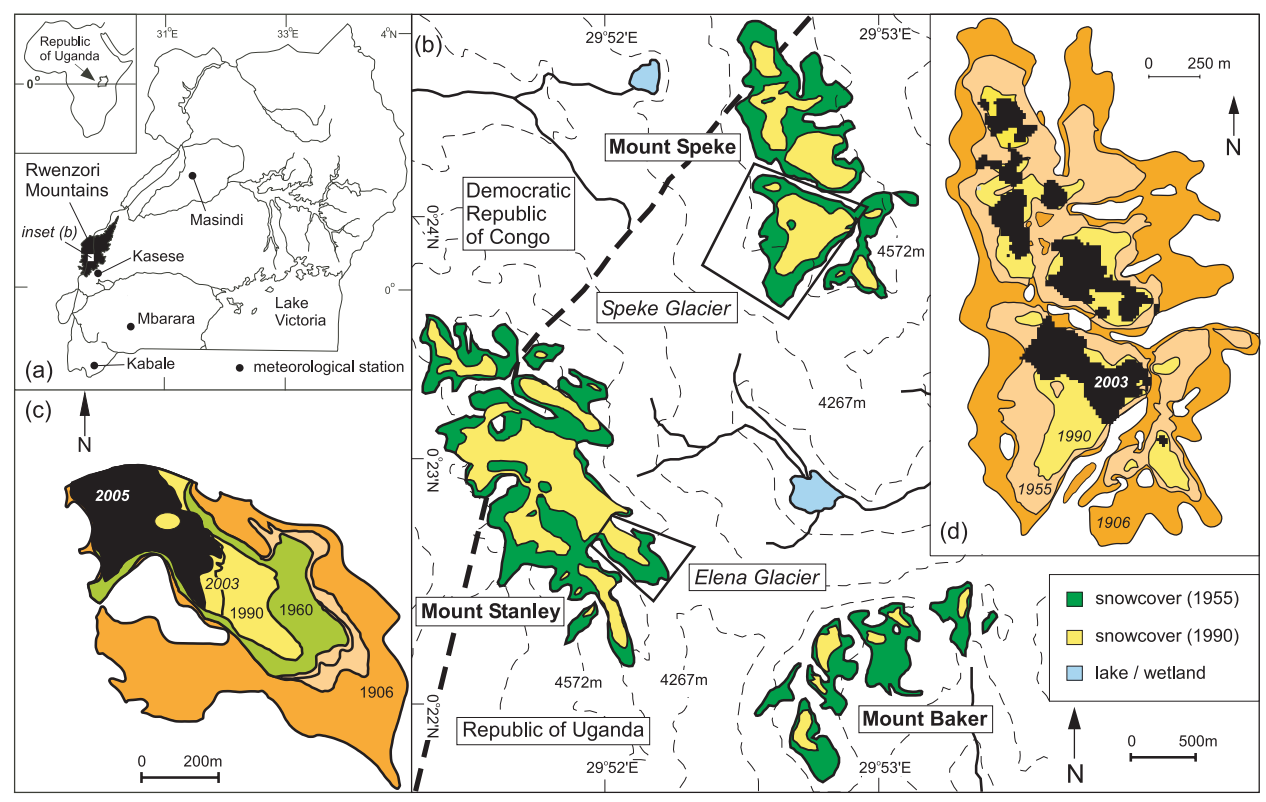

Figure 1. (a) Map of Uganda showing the location of the Rwenzori Mountains and meteorological stations. (b) The Central Rwenzori Massif showing indicator glaciers (Elena and Speke) and the extent of glacial cover in 1955 and 1990 [Kaser and Osmaston, 2002]. Topographic contours (interval: $305 \mathrm{~m}$ ) are in metres above mean sea level (originally in feet). (c) Changes in the terminus and areal extent of the Elena Glacier from 1906 to 2005. (d) Subsample of the NDSIclassified LandSat7 ETM+ satellite image on January 31, 2003 for Mount Speke superimposed on mapped glacier extents in 1906, 1955 and 1990 [Kaser and Osmaston, 2002].

contrasts the brightness of snow in band 2 with its low reflectivity in band 5. For the most recent (2003) image, field surveys assisted in supervision of classification of glacial cover and confirming the applied NDSI threshold distinguishing glacial cover from rock.

$$
N D S I=\frac{\text { band } 2-\text { band } 5}{\text { band } 2+\text { band } 5}
$$

\section{Results}

[7] Field surveys of the terminal positions of the Speke and Elena Glaciers demonstrate a continuation of the overall trend of recession observed between 1906 and 1990. The terminus of the Elena glacier has retreated by $\sim 400 \mathrm{~m}$ since 1906 and $140 \mathrm{~m} \pm 17 \mathrm{~m}$ since 1990 (Figure 1c). Terminal retreat on the Speke glacier is more rapid, $\sim 600 \mathrm{~m}$ since 1906 and $311 \mathrm{~m}$ since 1993 (Figure 1d). The contrasting rates are considered to result primarily from differences in the supply of ice to these valley glaciers as a result of their elevation and bed morphology (Figure 1b).

[8] Analyses of LandSat imagery using supervised classification (SC) and NDSI identify a $~ 50 \%$ decrease in the total area of glaciers from $1987\left(2.01 \pm 0.11 \mathrm{~km}^{2}\right)$ to 2003 $\left(0.96 \pm 0.34 \mathrm{~km}^{2}\right)$. Broad agreement exists between estimates of glacial cover $(<12 \%$ difference) derived from each method (Table 1). The results of the NDSI-classified, LandSat image from 1987 are consistent with historical data derived from aerial and terrestrial photography [Kaser and Noggler, 1996; Kaser and Osmaston, 2002]. Outlines of glacial extent on Mount Speke mapped by Kaser and Osmaston [2002] for 1906, 1955 and 1990 are overlain on a subsample of the NDSI-classified LandSat7 image from 2003 in Figure 1d. High reflectance areas (pixels), classified as glacial cover, clearly demonstrate the loss of glacial cover at lower elevations since 1990 .

[9] The recent field surveys and satellite mapping of glacial cover on the Central Rwenzori Massif show continued rapid reduction in glacial extent (Figure 2) since the last field measurements were taken in the early 1990s [Kaser and Noggler, 1991; Talks, 1993; Kaser and Noggler, 1996; Kaser and Osmaston, 2002]. Measurements over the last century indicate a relatively steady rate of decline in glacial extent though linearity $\left(r^{2}=0.999\right)$ in the rate of recession may derive, in part, from the limited number and uneven distribution of observations. Advance of the Speke Glacier was, for instance, detected during a period (1961 to 1962) of frequent monitoring and anomalously high precipitation [Temple, 1967]. Glaciers in the Rwenzori Mountains are, nevertheless, expected to disappear within the next two

Table 1. Areal Extent of Glacial Cover $\left(\mathrm{km}^{2}\right)$ on the Central Rwenzori Massif (Figure 1b)

\begin{tabular}{llllll}
\hline Year & Method & Baker, $\mathrm{km}^{2}$ & Speke, $\mathrm{km}^{2}$ & Stanley, $\mathrm{km}^{2}$ & Total, $\mathrm{km}^{288}$ \\
\hline $1906^{\mathrm{b}}$ & & 1.47 & 2.18 & 2.85 & 6.50 \\
$1955^{\mathrm{b}}$ & & 0.62 & 1.31 & 1.88 & 3.81 \\
$1987^{\mathrm{c}}$ & SC & $0.43 \pm 0.13$ & $0.65 \pm 0.18$ & $1.03 \pm 0.25$ & $2.11 \pm 0.56$ \\
& NDSI & $0.38 \pm 0.04$ & $0.63 \pm 0.02$ & $1.00 \pm 0.05$ & $2.01 \pm 0.11$ \\
$1990^{\mathrm{b}}$ & & $0.12 \pm 0.01$ & $0.56 \pm 0.06$ & $1.00 \pm 0.10$ & $1.68 \pm 0.17$ \\
$1995^{\mathrm{c}}$ & SC & $0.21 \pm 0.06$ & $0.45 \pm 0.11$ & $0.69 \pm 0.15$ & $1.35 \pm 0.32$ \\
& NDSI & $0.20 \pm 0.09$ & $0.44 \pm 0.17$ & $0.86 \pm 0.10$ & $1.50 \pm 0.36$ \\
$2003^{\mathrm{c}}$ & SC & $0.16 \pm 0.05$ & $0.40 \pm 0.08$ & $0.53 \pm 0.09$ & $1.09 \pm 0.22$ \\
& NDSI & $0.11 \pm 0.03$ & $0.35 \pm 0.11$ & $0.50 \pm 0.20$ & $0.96 \pm 0.34$ \\
\hline
\end{tabular}

${ }^{\mathrm{a}}$ Estimated errors derive from the classification and geometry of pixels.

${ }^{\mathrm{b}}$ Kaser and Osmaston [2002].

${ }^{\mathrm{c}}$ This study. 


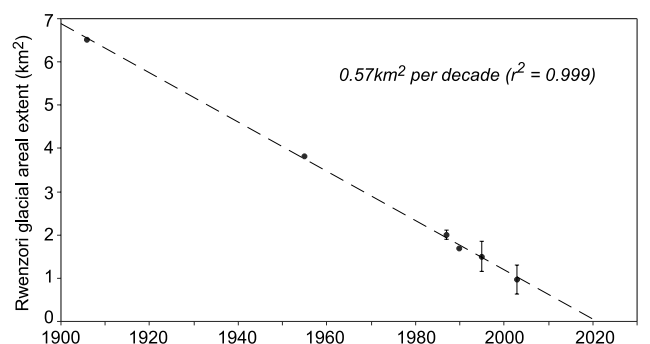

Figure 2. Plot of changes in glacial areal extent on Rwenzori Mountains since 1906. Data from 1906, 1955 and 1990 derive from Kaser and Osmaston [2002]. Remaining observations derive from NDSI classification of Landsat 5 (TM) and Landsat $7(\mathrm{ETM}+)$ scenes (Table 1).

decades if deglaciation continues to follow the observed linear trend (Figure 2).

\section{Meteorological Trends}

[10] The absence of continuous and proximate meteorological observations in the Rwenzori Mountains prevents direct analysis of the climatic factors driving observed glacial recession. Previous studies of glacial dynamics in the East African Highlands [e.g., Kruss and Hastenrath, 1987; Kaser and Noggler, 1991; Mölg et al., 2003; Kaser et al., 2004] contend that recession over the 20th century arises principally from an abrupt decrease in humidity at the end of the 19th century (ca. 1880). Decreased humidity increases the exposure of glaciers to solar radiation through reduced cloud cover. An associated decline in precipitation lowers accumulation and increases absorption of radiation due to the lower albedo of ice, relative to snow [Mölg et al., 2003; Kaser et al., 2004]. As a result, the rate of glacier net mass loss consequently rises.

[11] Hastenrath [2001] citing studies on Mount Kenya [Kruss, 1983; Hastenrath and Kruss, 1992], posits that glacial recession in the East African Highlands beyond the early decades of the 20th century has been promoted by a warming trend that has increased atmospheric humidity. This inhibits sublimation and permits more of the sun's energy to melt glacial ice due to a saving of latent heat. This has been well demonstrated on the Zongo and Chaccaltaya glaciers in Bolivia where higher melt rates in the wet season (i.e., period of increased humidity) result from reduced sublimation [Wagnon et al., 1999; Francou et al., 2003]. Though differential recession of glaciers in response to variations in solar incidence has been proposed for the Rwenzori Mountains [Mölg et al., 2003], the spatially uniform loss of glacial cover in the Rwenzori Mountains at lower elevations over the last decade strongly suggests increased air temperature is the main driver.

[12] Terrestrial observations of air temperature are consistent with a warming trend indicated by recent glacial recession. Daily records of maximum and minimum air temperature at meteorological stations east of the Rwenzori range between latitudes of $1^{\circ} 41^{\prime} \mathrm{N}$ and $1^{\circ} 15^{\prime} \mathrm{S}$ in Uganda (Figure 1a) show significant (at confidence intervals of $99 \%$ or greater) and consistent trends toward increased air temperatures of $\sim 0.5^{\circ} \mathrm{C}$ per decade since the last period of glacial advance in the early 1960s (Figure 3). These data contain, however, significant gaps and are limited in dura- tion. Gridded climate data [New et al., 2002] for the grid cell closest to the Rwenzori Mountains $\left(0^{\circ} 50^{\prime} \mathrm{N}, 29^{\circ} 30^{\prime} \mathrm{E}\right)$ also demonstrate a small but significant rise in mean surface temperature of $0.15^{\circ} \mathrm{C}$ per decade from 1960 to 1998 that is consistent with a regional warming trend of the same magnitude determined by Patz et al. [2002]. Because of the thermal homogeneity of the troposphere in the inner tropics [Kaser and Osmaston, 2002; Oerlemans, 2005], the recent (post-1960) rise in air temperature observed at stations between 960 and 1869 mamsl is also expected to occur in areas of glacial cover between 4800 and 5100 mamsl.

[13] The possibility that recent glacial recession arises from a reduction in precipitation is unsupported by station data in western Uganda (Figure 1a) over the 20th century. Considerable interannual variability is evident but no significant trends in annual precipitation since 1960 are detectable. Records of riverflow in Uganda with headwaters

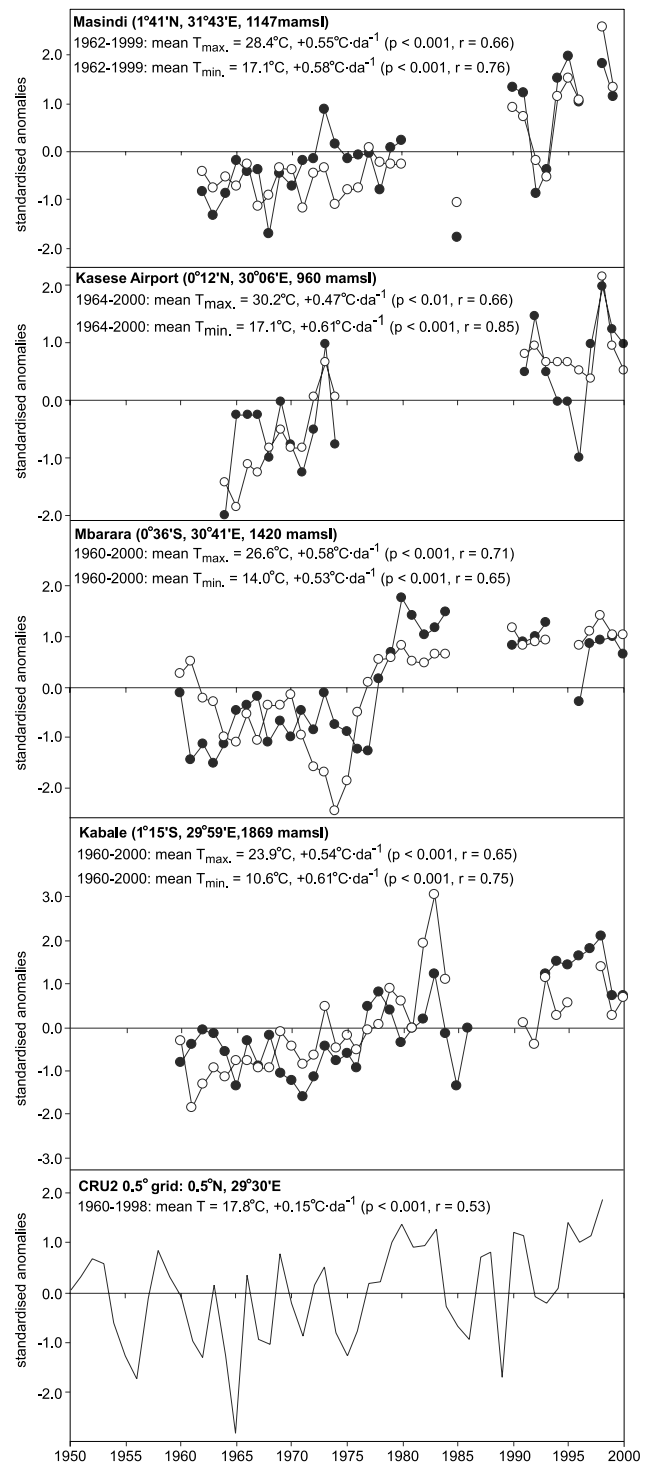

Figure 3. Standardised anomalies in annual mean maximum (solid circles) and mean minimum (open circles) air temperature observed at meteorological stations in western Uganda and annual mean temperature from gridded CRU2 climate data [New et al., 2002] over the 20th century. 
above 3000 mamsl in the Rwenzori Mountains provide a potential proxy of highland precipitation but are too limited in duration to enable an evaluation of climatological trends. Although there is historical evidence of a reduction in humidity in East Africa beginning around 1880 [Nicholson and Yin, 2001], meteorological records are insufficient to investigate whether a posited warming trend starting in the 19th century [Oerlemans, 2005] also contributed to the onset of deglaciation in the East African Highlands.

\section{Conclusions}

[14] Recent field mapping and analysis of Landsat imagery confirm a rapid decline in the areal extent of glaciers on the Central Rwenzori Massif that is consistent with an overall recessionary trend over the 20th century. Glacial cover on the three remaining glacierised summits (Mounts Stanley, Speke and Baker) has decreased from $2.01 \pm 0.56$ $\mathrm{km}^{2}$ in 1987 to $0.96 \pm 0.34 \mathrm{~km}^{2}$ in 2003 and is expected to disappear within the next two decades. Increased air temperature suggested by the spatially uniform nature of recent loss of glacial cover at lower elevations is supported by station data in western Uganda and gridded climate data sets. The observed rise in air temperatures over the last four decades is also consistent with warming trends predicted in the tropical troposphere from climate model simulations that incorporate historical increases in greenhouse gases [Santer et al., 2005].

[15] Acknowledgments. We thank Henry Osmaston, Georg Kaser and Andrea Fischer for their helpful comments on the manuscript. Research was conducted with the permission and cooperation of Uganda National Council for Science and Technology (EC583) and Uganda Wildlife Authority. Research was supported primarily by grants from the Royal Geographical Society (Ralph Brown Award) and The Royal Society.

\section{References}

Abruzzi, L. (1907), The snows of the Nile, Geogr. J., 29, 121-147.

Bergstrøm, E. (1955), British Ruwenzori expedition, 1952: Glaciological observations-Preliminary report, J. Glaciol., 2, 468-473.

Francou, B., M. Vuille, P. Wagnon, J. Mendoza, and J. Sicart (2003), Tropical climate change recorded by a glacier in the central Andes during the last decades of the twentieth century: Chacaltaya, Bolivia, $16^{\circ}$ S, J. Geophys. Res., 108(D5), 4154, doi:10.1029/2002JD002959.

Hastenrath, S. (2001), Variations of East African climate during the past two centuries, Clim. Change, 50, 209-217.

Hastenrath, S., and P. D. Kruss (1992), The dramatic retreat of Mount Kenya's glaciers between 1963 and 1987: Greenhouse forcing, Ann. Glaciol., 16, 127-133.

Hay, S. I., et al. (2002), Climate change and the resurgence of malaria in the East African highlands, Nature, 415, 905-909.
Kaser, G., and B. Noggler (1991), Observations of Speke Glacier, Ruwenzori Range, Uganda, J. Glaciol., 37, 313-318.

Kaser, G., and B. Noggler (1996), Glacier fluctuations in the Ruwenzori Range (East Africa) during the 20th century-A preliminary report, $Z$. Gletscherkd. Glazialgeol., 32, 109-117.

Kaser, G., and H. Osmaston (2002), Tropical Glaciers, p. 207, Cambridge Univ. Press, New York.

Kaser, G., et al. (2004), Modern glacier retreat on Kilimanjaro as evidence of climate change: Observations and facts, Int. J. Climatol., 24, 329-339. Kite, G. W. (1981), Recent changes in level of Lake Victoria, Hydrol. Sci. Bull., 26, 233-243.

Kruss, P. D. (1983), Climate change in East Africa: A numerical simulation from 100 years of terminus record at the Lewis Glacier, Mount Kenya, Z. Gletscherkd. Glazialgeol., 19, 43-60.

Kruss, P. D., and S. Hastenrath (1987), The role of radiation geometry in the climate response of Mount Kenya's Glaciers: part 1: Horizontal reference surfaces, Int. J. Climatol., 7, 493-505.

Mölg, T., et al. (2003), The contribution of increased incoming shortwave radiation to the retreat on the Rwenzori glaciers, east Africa, during the 20th Century, Int. J. Climatol., 23, 291-303.

New, M. G., et al. (2002), A high-resolution data set of surface climate for terrestrial land areas, Clim. Res., 21, 1-25.

Nicholson, S. E., and X. Yin (2001), Rainfall conditions in equatorial East Africa during the nineteenth century as inferred from the record of Lake Victoria, Clim. Change, 478, 387-398.

Oerlemans, J. (2005), Extracting a climate signal from 169 glacier records, Science, 308, 675-677.

Osmaston, H. (1989), Glaciers, glaciations and equilibrium line altitudes on the Rwenzori, in Quaternary and Environmental Research on East African Mountains, edited by W. C. Mahaney, pp. 31-104, Taylor and Francis, Philadelphia, $\mathrm{Pa}$.

Patz, J. A., et al. (2002), Regional warming and malaria resurgence, Nature, 420, 627-628.

Santer, B. D., et al. (2005), Amplification of surface temperature trends and variability in the tropical atmosphere, Science, 309, 1551-1556.

Talks, A. (1993), East African hot ice 1993, internal report, Sir Roger Manwood's Sch., Kent, U.K.

Temple, P. H. (1967), Further observations on the glaciers of the Ruwenzori, Geogr. Ann., Ser. A, 50, 136-150.

Thompson, L. G., et al. (2002), Kilimanjaro ice core records: Evidence of Holocene climate change in tropical Africa, Science, 298, 589-593.

Vogel, S. W. (2002), Usage of high-resolution Landsat 7 band 8 for single band snow-cover classification, Ann. Glaciol., 34, 53-57.

Wagnon, P., P. Ribstein, B. Francou, and B. Pouyaud (1999), Annual cycle of energy balance of Zongo Glacier, Cordillera Real, Bolivia, J. Geophys. Res., 104, 3907-3924.

Whittow, J. B., et al. (1963), Observations on the glaciers of the Rwenzori, J. Glaciol., 4, 581-615.

A. Majugu, Meteorology Department, P.O. Box 7025, Kampala, Uganda. L. Mileham and R. G. Taylor, Department of Geography, University College London, 26 Bedford Way, London WC1H 0AP, UK. (r.taylor@ geog.ucl.ac.uk)

A. Muwanga, Department of Geology, Makerere University, P.O. Box 7504, Kampala, Uganda.

B. Nakileza, Department of Geography, Makerere University, P.O. Box 7504, Kampala, Uganda.

C. Tindimugaya, Water Resources Management Department, Directorate of Water Development, P.O. Box 19, Entebbe, Uganda. 